\title{
PUPILS' VOCABULARY DEVELOPMENT THROUGH ASSOCIATION STRATEGY IN EFL LEARNING
}

\begin{abstract}
This paper featured reviewing the usage of association strategy in showing EFL vocabulary to the pupils. This examination utilized an accommodating report hallway activity research plan and it was done as cycles containing four tremendous advances: organizing, executing, seeing and reflecting. The subject of the examination was 80 pupils in Indonesia. The instruments used to collect information were test, acumen plans, and field notes. This examination was done in two cycles considering the way that the deferred results of the appraisal in the fundamental cycle didn't meet the rules of accomplishment. All of cycle incorporates four get-togethers. The disclosures of the examination showed that the applying of procedure in getting ready English can manufacture pupils' vocabulary strength. This is appeared by the pupils' gainful rate in cycle I was 52 (65\%), in Cycle II and the measure of the pupils who got scores at any rate 6.5 or more basic was $70(87.5 \%)$. Additionally, the pupils gave positive reaction toward the insight plan result, explicitly: excitement, inspiration, interest, reaction, and progress. It very well may be considered that the association system is successful and material in educating vocabulary.
\end{abstract}

Keywords: EFL students, vocabulary, association strategy

In showing English, vocabulary anticipates an enormous part in building up the four language limits, for example talking, tuning, recorded as a printed form, and looking at. In addition, they are kept up by language parts like vocabulary and syntax (Dorry and Zeaman, 1973; Nation, 2003; Schmitt, 2007; Mehrpour, 2008; Marzuki, 2017a; Marzuki, 2017c).

English educators in the evaluation school are should have been imaginative to raise the pupils' learning inspiration and make them enthused about learning English vocabulary. They need to utilize dazzling and fitting techniques in showing vocabulary, like singing a tune, utilizing pictures, utilizing streak cards, and utilizing union framework (Nuessel and Cicogna , 1994; Hunt and Beglar, 2002; Nichols and Rupley , 2004; Marzuki, 2016a; Farangiz, 2017; Marzuki, 2017b) .

Considering the expert's exposures through understanding and her experience showing school, the vast majority of the pupils particularly for the 6th grade pupils didn't have even the remotest piece of information about the basic English words subject to the appearance theme in the appearance material, for example, words identified with diversion activities, food and drink, transportation, and occupation. What's more, they were now difficult to disclose English words and to hold their significance so they continue to consider whether to give in English. They truly experienced issues in utilizing English reasonably in both oral and shaped correspondence since they need vocabulary. They had bound words, so they discover bother to bestow their insights 
(Marzuki, 2016b; Fatimah and Santiana, 2017; Marzuki and Fitriningsih, 2017; Santiana and Fatimah, 2017).

Truth be told, the instructor's appearance style and the procedure that applied by the teacher gave an astonishing commitment to the condition. Two or three realities were discovered identified with the appearance vocabulary: (1) the instructor offered out to pupils to recall certain words found in the course examining or in the word reference; and (2) the teacher referenced that the pupils discover risky words or new words by then made an interpretation of them into Indonesian. The strategies applied by the teacher don't have every one of the reserves of being productive since they don't give a huge load of duty in building up pupils' vocabulary prevalence. The master additionally believed that unseemly engaging system applied by the educator might be the defense the low capacity of the pupils in learning English.

In this matter, the affiliation technique with word affiliation is one of the responses for develop the pupils' vocabulary when they see something or hear a couple of words. For instance, the teacher gave the sign 'tree' and mentioned the pupils to make reference to parts from the tree. The pupils notice them like leaf, natural item, and branch. Accordingly, this investigation is assisted and entitled Teaching Vocabulary through Association Strategy.

The investigator utilized an enthusiastic appraisal drove by applying homeroom activity research plan. It covered between basic parts containing arranging, execution, knowledge, and reflection. These directed relationship of enabling vocabulary through word association find in the key pupils. Kemmis and McTaggart: "Activity research begins with little instances of status, acting, seeing and reflecting which can assist with depicting issues, thoughts, and suspicions significantly more clearly so those consolidate can portray all of the more extraordinary solicitations from themselves as their work moves." (Kemmis and McTaggart, 1988; McNiff, 1992; McMillan and Schumacher, 1993; Bogdan and Biklen, 1998).

Pupils' improvement

The pupils' improvement in vocabulary through letters all together cards were researched and isolated through assessment season of the appearance learning measure. The master zeroed in on the three rules of accomplishment where she expected to take a gander toward the fruition of cycle. To give better comprehension toward the exposures, the postponed result of assessment will be explained as follows:

a. Meeting in cycle I

To isolate the three models of accomplishment, the analyst used affiliation strategy, knowledge enlistment, and field notes. The possible result of assessment was that from the standard fundamental of the cycle 1 it was found there were fifteen of thirty pupils who got "unbelievable" or "incredible" score. It proposed that the pupils' convincing rate that got achievement level from the central primer of cycle I had not currently meet the standards of accomplishment. Since, the rate approach utilized recipe 52x100\%:80 $=65 \%$. 52 was the measure of pupils who got achievement capacity; 80 was the sum, considering everything, and 100 is the deviation scale. Obviously, the level of study hallway achievement ought to be $65 \%$ of the measure of pupils. 
b. meeting in cycle 2

The possible result of assessment toward evaluation on cycle II party 4 evoked the enormous upgrade for pupils' vocabulary. During that time test in cycle II; it was discovered that there were 70 pupils who got "achievement" capacity. It proposes that the measure of pupils who got "achievement" from the second examination of cycle II has fulfilled the rules of progress; considering the way that the rate approach utilizes condition $70 \times 100 \%: 80=87.5 \%$. 70 is the measure of pupils who get "achievement" limit; 80 is the sum, considering everything, and 100 is the deviation scale. Since the measure of pupils who got "achievement" limit in excess of a piece of undeniably the amount of pupils (87.5\%), so it is accumulated that the models of study passage accomplishment has been developed.

Considering the procedures finished above, by then the examiner introduced the outcomes: first, the educating of English vocabulary through affiliation framework can create pupils' vocabulary strength particularly they ought to have more vocabulary for in any event 500 words in term of the significance and how to express the words. Second, by separating the result of' pupils' accomplishment in the standard cycle, the pupils' accomplishment on second cycle has huge new turn of events. This can be concentrated from the pupils' practical level of spelling test in cycle I was 52 pupils (65\%) be reached out to 70 pupils (87.5\%) in cycle II. Third, association strategy can request that pupils be dynamic to join study entryway works out. By giving a word dependent upon the point talked about and referenced that they accessory the words, the pupils battle in responding to the solicitation, doing the assignments, spelling and rehearsing to express the words. In addition, last, the pupils had positive reaction toward the applying of affiliation system in learning vocabulary. This method could build up pupils' energy, inspiration, interest, reaction, and progress in joining the class and finishing the homeroom assignments.

\section{REFERENCES}

Dorry, G. W., \& Zeaman, D. (1973). The Use of a Fading Technique in Paired-Associate Teaching. Mental Retardation, 11(6), 3.Elyas, T. (2014). Teaching vocabulary: The relationship between techniques of teaching and strategies of learning new vocabulary items.

Farangiz, R. O. (2017). Modern Principles, Methods of Teaching Vocabulary. In Научнотехнический прогресс: актуальные и перспективные направления будущего (pp. 277278).

Marzuki, A.G. (2016a). Developing reading skill of islamic education department students through guided reading. Paedagogia: Jurnal Pendidikan, 5(2), 235-257.

Marzuki, A.G. (2016b). Utilizing cooperative learning in islamic college students' classroom. IJEE (Indonesian Journal of English Education), 3(2), 123-139.

Marzuki, A.G. (2017a). Applying mind mapping technique in improving english vocabulary mastery in an efl classroom. Paedagogia: Jurnal Pendidikan, 6(2), 276-293. 
Marzuki, A.G. (2017b). Developing speaking skill through oral report in an efl class in indonesia. Al-Ta lim Journal, 24(3), 243-254.

Marzuki, A.G. (2017c). Utilizing pictures in increasing pupils' vocabulary mastery in an efl class in palu city indonesia. Musawa: Journal for Gender Studies, 9(2), 191-233.

Marzuki, A.G., \& Fitriningsih, F. (2017). Developing speaking skill of the third semester students of tbi ftik iain palu through tablemate interview. Paedagogia: Jurnal Pendidikan, 6(1), 134-167.

McMillan, J.H. and Schumacher, S. 1993. Research in Education. A Conceptual Introduction. Harper Collins Publisher, Virginia.

McNiff, J. 1992. Action Research: Principle and Practice. Chapman and Hall, Inc., New York.

Mehrpour, S. (2008). A comparison of the effects of two vocabulary teaching techniques. The Asian EFL Journal, 10(2), 192-208.Kemmis, S. and McTaggart, R. 1988. The Action Research Planer. Australia. Deakin University.

Nation, P. (2003). Materials for teaching vocabulary. Developing materials for language teaching, 394-405.

Nichols, W. D., \& Rupley, W. H. (2004). Matching instructional design with vocabulary instruction. Reading Horizons: A Journal of Literacy and Language Arts, 45(1), 4.

Santiana, S., \& Fatimah, A. S. (2017). Prezi, Cloud-Based Presentation, for Teaching: How is it Interesting?. EduLite: Journal of English Education, Literature and Culture, 2(2), 445-456.

Schmitt, N. (2007). Current perspectives on vocabulary teaching and learning. International handbook of English language teaching, 827-841.

Nuessel, F., \& Cicogna, C. (1994). Strategies for teaching vocabulary in the elementary and intermediate Italian classroom. Italica, 71(4), 521-547. 